TECHNICAL TRANSACTIONS 7/2017

CZASOPISMO TECHNICZNE 7/2017

MECHANICS

DOI: $10.4467 / 2353737$ XCT.17.118.6659

Andrzej Opaliński (andrzej.opalinski@agh.edu.pl)

Faculty of Metals Engineering and Industrial Computer Science, AGH University

of Science and Technology

Mirosław Głowacki (glowacki@metal.agh.edu.pl)

Faculty of Mathematics and Natural Science, The Jan Kochanowski University, Kielce

Faculty of Metals Engineering and Industrial Computer Science, AGH University of Science and Technology

\title{
MOBILE REMOTE MONITORING SYSTEM OF WATER RESERVOIRS
}

MOBILNY SYSTEM ZDALNEGO MONITORINGU ZBIORNIKÓW WODNYCH

\begin{abstract}
The article presents the concept, architecture and testing of mobile monitoring system of water reservoirs. Its main elements are a remotely controlled boat with a sonar, which additionally records GPS data. The developed system could be used in several configurations for the achievement of functions such as generating bathymetric maps or the current monitoring of the bottom of a water reservoir. The main functionalities of the system have been tested and presented with the results of the tests and their analysis, conclusions and plan of further development.
\end{abstract}

Keywords: bathymetric maps, bottom monitoring, mobile systems

\section{Streszczenie}

W artykule przedstawiono koncepcję, architekturę oraz testy mobilnego systemu monitoringu zbiorników wodnych. Jego głównymi elementami są zdalnie sterowana łódź oraz echosonda rejestrująca dodatkowo dane GPS. Opracowany system może być wykorzystywany w kilku konfiguracjach, umożliwiając realizację funkcjonalności takich jak generowanie map batymetrycznych lub bieżący monitoring dna zbiornika wodnego. Główne funkcjonalności systemu zostały przetestowane i zaprezentowane wraz rezultatami testów, ich analiza, wnioskami i planem dalszego rozwoju

Słowa kluczowe: mapy batymetryczne, monitoring dna, systemy mobilne 


\section{Introduction and related works}

Oceans and other water reservoirs are one of the least explored areas on the Earth. The need for exploration of aquatic environments applies to both large areas which are seas and oceans, as well as smaller ones, such as lakes, rivers and smaller water reservoirs. Issues related to the exploration of these environments concerning their flora [2], fauna [5], the ecosystem [6] but also the structure and the type of bottom [3, 4], apply to issues of the presented article.

In general, the issue of testing water bottom has been the subject of research for a long time and on a fairly large scale $[1,7]$. Exploration of such environment is inherently difficult and expensive and requires sophisticated equipment, advanced data processing algorithms $[8,9]$ and a huge amount of financial resources $[10,11]$.

Another phenomenon that is constantly progressing in the world around us is the development of technologies, including electronic solutions, information technology and the new materials with increasingly better mechanical properties. All of this results in the possibility to create better systems and solutions, which perform their tasks faster, more accurately, efficiently and cheaper.

All these reasons have led the authors of this paper to undertake the task of developing a lowbudget system, which allows remote monitoring of water reservoirs. The main functionality of the proposed system is mapping of bathymetry of the tank and monitoring its bottom as well as the structure of its surface. The main feature that distinguishes this system from other currently used ones is the cost of its implementation. It does not exceed the amount of several thousand zlotys, which is a value at least one order of magnitude lower than the cost of other systems that are currently used in the field.

\section{System architecture}

The presented system consists of a number of hardware components and software which collectively provide the main functionality of the system. This section describes the hardware and the two main modes of operation of the whole system.

\subsection{Hardware components of the system}

Figure 1 shows the major hardware components included in the system. These are (according to the numbering placed on the drawing):

1) Remote controlled boat with a transducer sonar built on a solid in the hull, which sends and receives signals in order to obtain information at the bottom of the water reservoir. The boat has dimensions of $64 \times 41 \times 22 \mathrm{~cm}$ and weighs about $5 \mathrm{~kg}$ without battery. It is made of ABS plastic and is powered by two motors screw and a gel battery pack with a capacity of $12000 \mathrm{mAh}$.

2) Software for generating a bathymetric map and interpreting data obtained by an echo sounder. The system uses two different software data-processing components: 
ReefMasterPro (https://reefmaster.com.au/) and Insight Genesis (https:// gofreemarine.com/insight-genesis/).

3) Lowrance Elite-4 HDI sonar (depth sounder) allows for collecting data from the sonar transducer, recording the data on the microSD card and visualizing them live on a 4 inch screen. The sounder receives additional data regarding GPS position, which are then used to create bathymetric maps of reservoirs.

4) Wireless communication module with a sonar transducer designed for the needs of the system. The standard depth sounder is connected to the sonar transducer via a cable. In the case of this system, a wireless connection using radio transmission with a frequency of $868 \mathrm{MHz}$ was implemented. This allows the observation of data from the transmitter (from the boat) by the operator located on the shore of the water reservoir.

5) Wireless remote controller for the boat operating in the $2.4 \mathrm{GHz}$ band, which allows the system operator to control the boat on the water tank.
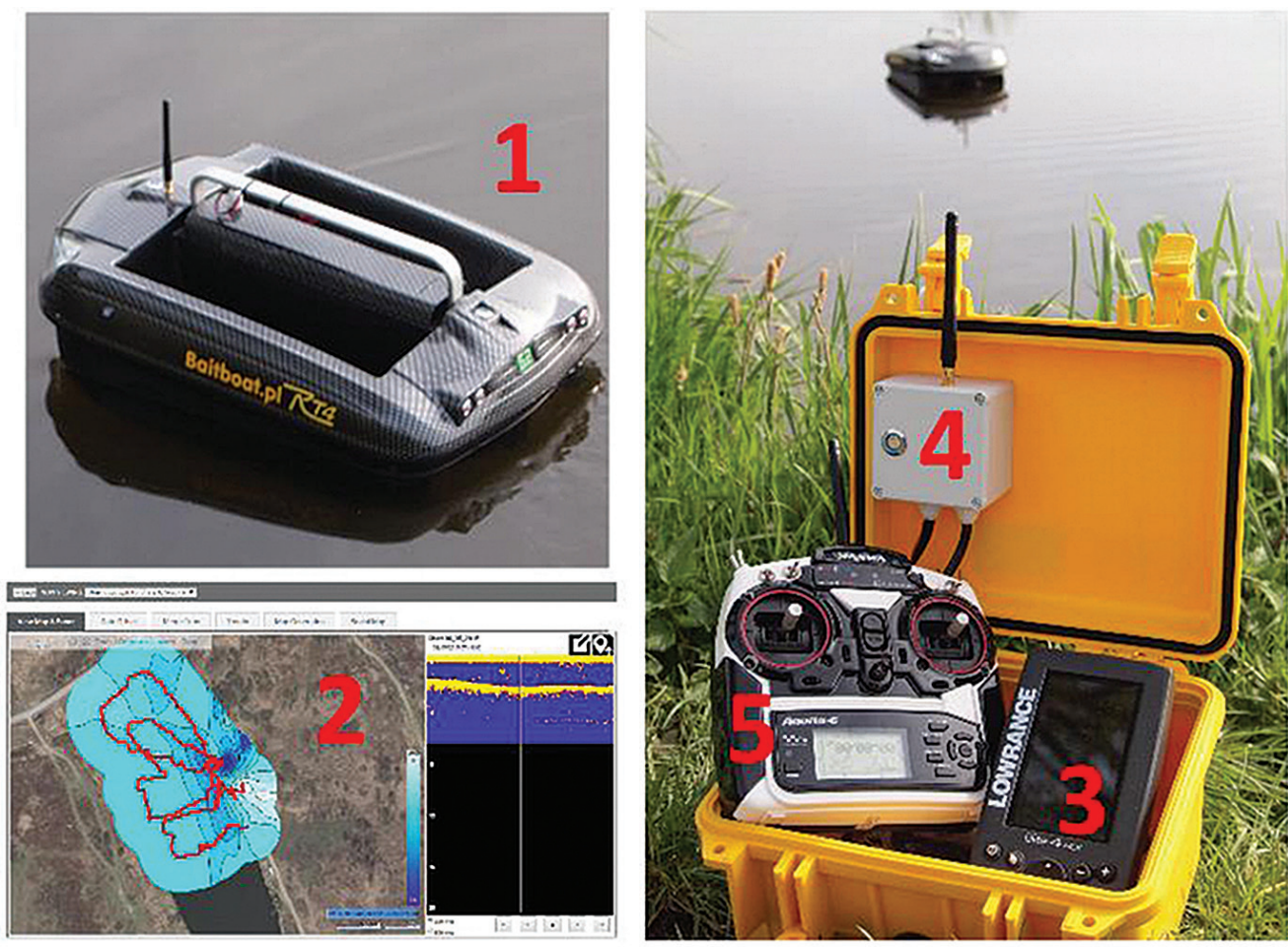

Fig. 1. Main hardware components of the system

The system consists of more battery packs, supplying power for the transducer and echo sounder. Those are placed in the middle of the bulkhead of the boat and near the sonar 


\subsection{Operating modes of the system}

Implemented concept of the system allows it to operate in two main modes. They differ in the hardware configuration of the system and functionalities implemented within each mode. Both modes are shown schematically in Fig. 2.

The first mode, as described in part a) of Fig. 2 generates bathymetric maps of water reservoirs. In this mode, the operator of the system is located on the shore with the remote boat controller, and depth sounder is mounted directly on the boat floating on the reservoir. This configuration allows for linking data obtained from the sonar transducer with GPS coordinates received via echo sounder. These data are stored on a microSD card inserted in the depth sunder and then used to generate a bathymetric map of the reservoir. In the mode where the sonar is in the boat, the operator does not have current (live) information about the monitored bottom of the reservoir. It could be obtained only by analyzing logs recorded on the card.

The second operation mode of the system as described in part b) of Fig. 2 is the bottom monitoring mode. In this mode, the depth sounder is on the shore of the reservoir and the operator has the ability to continuously monitor the information returned by the transducer sonar. In this mode, the information about GPS coordinates is not collected by default, as it is related to the location of the operator and not the boat.

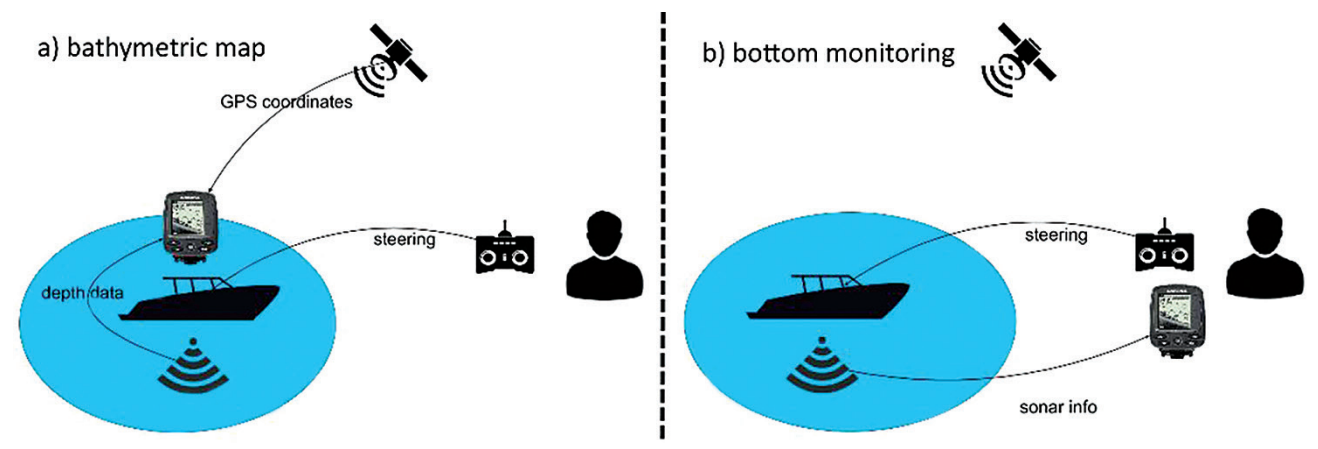

Fig. 2. Two main operating modes of the system

An additional functionality provided by the software used in the system is the ability to identify the bottom types of the reservoir, based on different characteristics of signals received by the signal processor.

\section{Application and results}

To evaluate the present system, a series of tests on its major features was carried out. The first test was to generate a bathymetric map of a body of water, while the other was to verify the effectiveness of the system in monitoring the bottom of the reservoir, including the detection of bottom type and finding the objects it contains. 


\subsection{Generating a bathymetric map of water reservoirs}

The test consisting in the generation of bathymetric maps of the reservoir was carried out on the reservoir Podgórki Tynieckie on the border of Cracow and Tyniec area. The test conducted 4 series of data collection (for a total of about 2 hours of boating), which allowed for generating a map of an area of about 10 hectares. A fragment of bathymetric map of the reservoir, along with the trace route and isobaths indicating its depth is presented in Fig. 3.

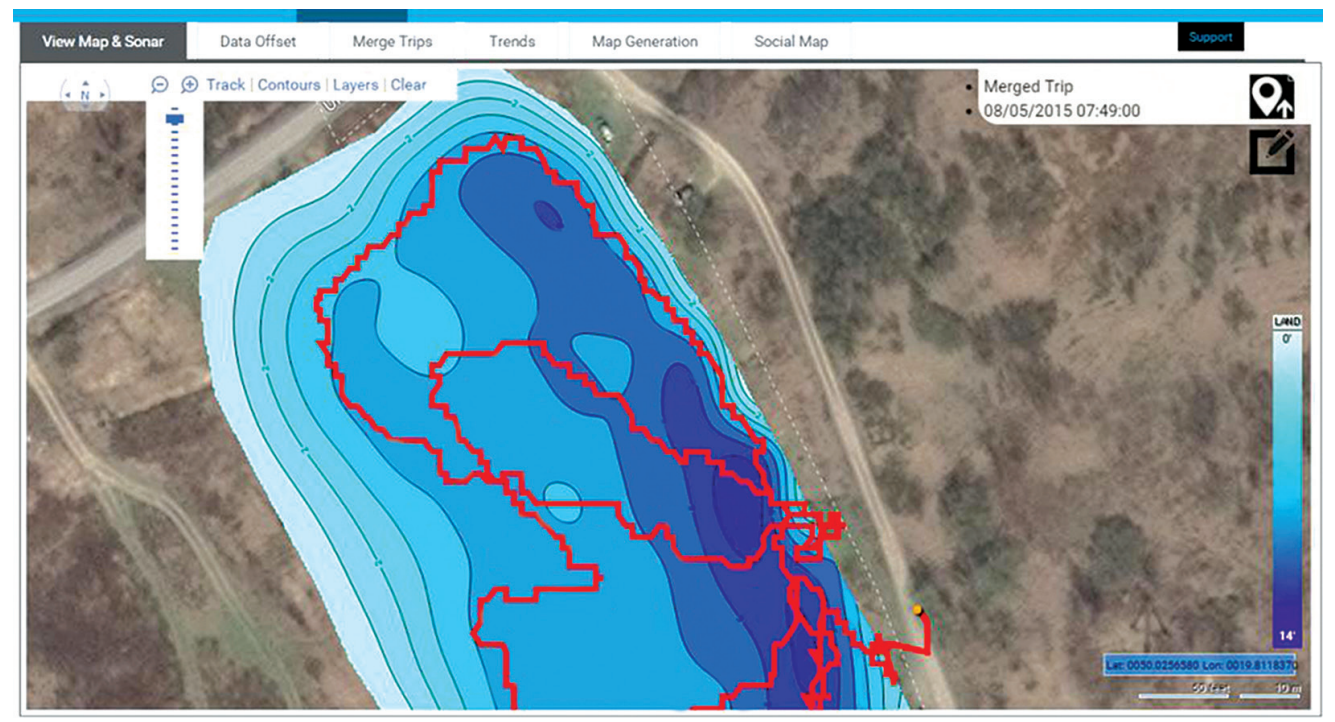

Fig. 3. Bathymetric map of Podgorki Tynieckie reservoir

The map has been developed using free environment Insight Genesis, and is publicly available on the https://gofreemarine.com/insight-genesis website.

\subsection{Bottom monitoring tests}

The second test conducted in order to verify the implementation of the assumptions associated with the system was mapping the bottom and estimating the possibility of using the system to detect objects at the bottom of the reservoir. For this purpose, we performed a series of tests on Zakrzówek reservoir in the city of Cracow. The element that has been selected for testing was sunk at the bottom of the reservoir. It was a wreck of a fishing boat with a length of about $20 \mathrm{~m}$ and a height of $5 \mathrm{~m}$, sunk to a depth of about $15 \mathrm{~m}$. A model of the sunk wreck is presented in part a) of Fig. 4 .

Elements associated with the process of monitoring the bottom are shown in part $b$ ) of Fig. 4. This process was carried out in two phases. In the first phase, the boat monitored the vicinity of the wreck in the configuration with the sonar on the boat (as in the mode 
a) wreck model

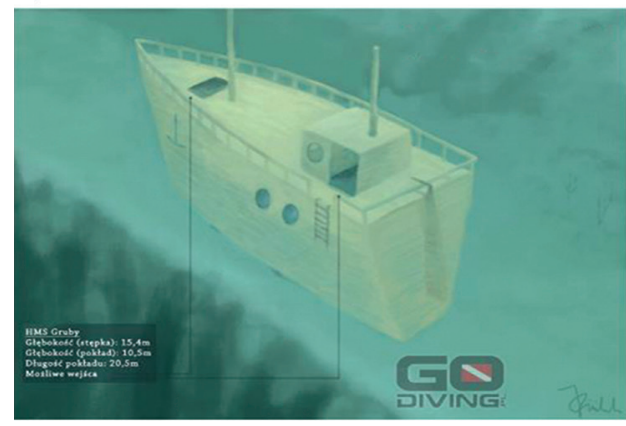

b) bottom monitoring

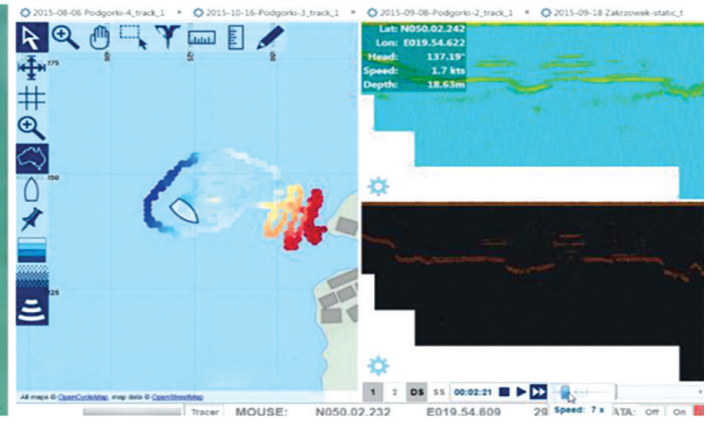

Fig. 4. a) Wreck model (http://godiving.pl) and b) software output for bottom monitoring

presented in Fig. 2a), which resulted in logs related to the GPS coordinates shown in Fig. 4b and 5 . In the second phase, the sonar was placed near the operator, who was able to monitor the information received from the sonar transducer in a real time. The data obtained in this manner were identical with those on the far right of Fig. $4 \mathrm{~b}$. There we can see that during the passage of the boat on the wreck, sharp fluctuations in depth can be seen, which can be interpreted as passage above the level of the deck and wheelhouse later. Immediately, there comes the idea to use these data to carry out a three-dimensional visualization of the object, which in the current version of the system is not available.

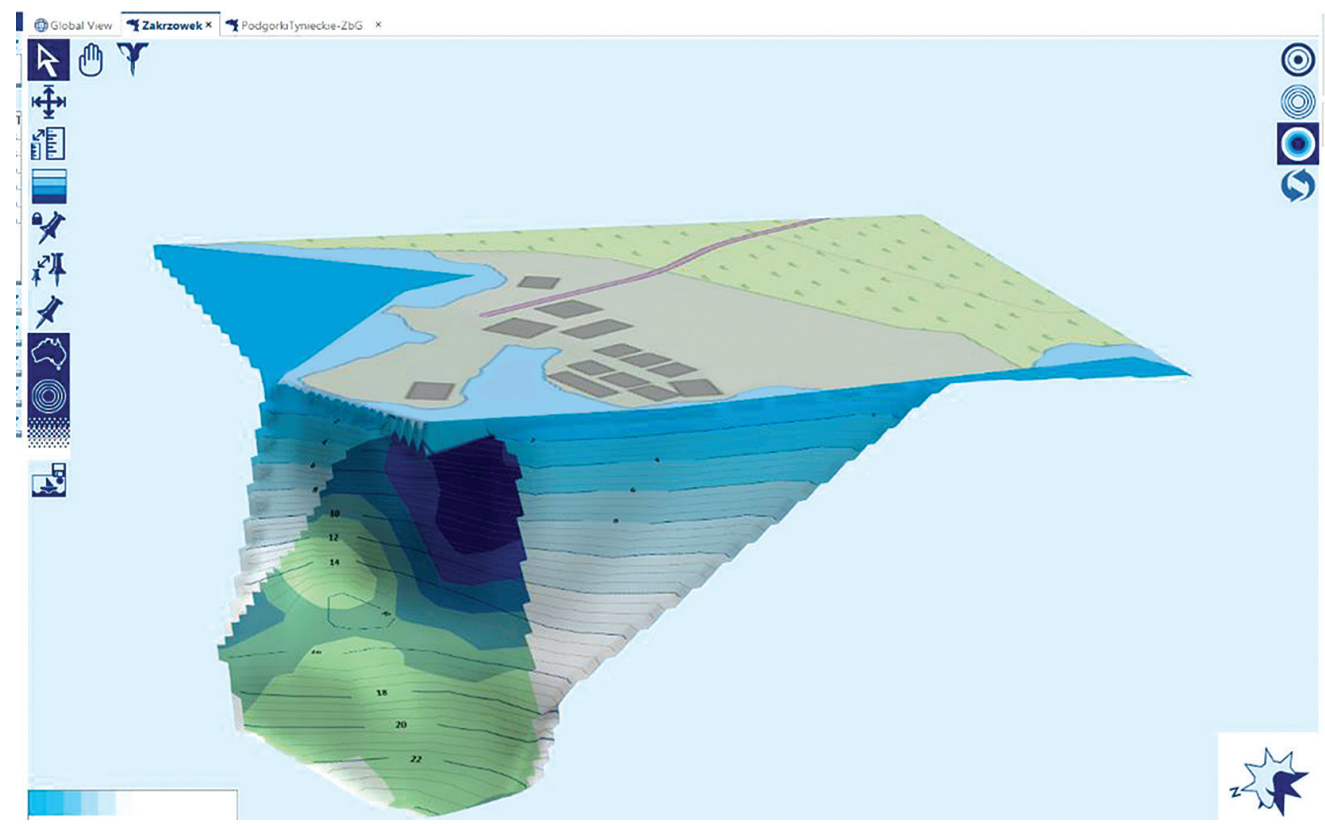

Fig. 5. Bottom types detection 
Another stage of this test was to evaluate the ability to generate maps of the bottom of the reservoirs with respect to the types of the substrate, which is illustrated in Fig. 5. We can see the actual difference between the bottom layers, which roughly corresponded to the actual changes occurring on the reservoir. The conclusions of this part of the study are that the full implementation of this functionality requires an additional calibration of the signal level corresponding to various types of substrate and taking them into account in the process of interpreting the results.

The tests carried out have confirmed the practical implementation of goals, involving the development of a system for generating a bathymetric map and monitoring water reservoirs bottom.

\section{Conclusions and future works}

The developed system presented in this article allows for generating bathymetric maps and monitoring water bottoms. The system implemented in this architecture is much cheaper compared to the currently used professional solutions found in this area. Bathymetric maps obtained by means of the presented system are characterized by relatively high accuracy. The process of bottom monitoring provides accurate data on the depth and basic information about objects at the bottom. It can be developed in the direction of a more accurate visualization of the objects placed at the bottom of the reservoir. In this case it would be necessary to use more advanced devices such as side-scanners and efficient algorithms for processing spatial data. Another direction of development of the presented system is the automation of modules associated with boat control. The mechanism of auto-navigation would greatly facilitate the process of collecting data and generating maps, eliminating the human factor responsible for the manual control of the boat in order to cover the entire area of the reservoir. The presented the system appears to be a promising platform for further development and works in a wide range of issues of science and technology related to water reservoirs monitoring and surveys.

The work has been supported by the Polish Ministry of Science and Higher Education - AGH University of Science and Technology Funds No. 11.11.110.300

\section{References}

[1] Hakanson L., A manual of lake morphometry, Springer Science \& Business Media, 2012.

[2] Paira, A. R., Drago, E. C., Origin, evolution, and types of floodplain water bodies, [in:] The Middle Paraná River, Springer Berlin Heidelberg, 2007, 53-81.

[3] Ng, S. L., Sin, F. S., A diatom model for inferring sea level change in the coastal waters of Hong Kong, Journal of Paleolimnology, 2003, 30(4), 427-440. 
[4] Sobek, S., Nisell, J., Fölster, J., Predicting the volume and depth of lakes from map-derived parameters, Inland Waters, 2011, 1(3), 177-184.

[5] Joyeux, J. C., \& Ward, A. B., Constraints on coastal lagoon fisheries, Advances in Marine Biology, 1998, 34, 73-199.

[6] Drago, E. C., The physical dynamics of the river-lake floodplain system, [in:] The Middle Paraná River Springer Berlin Heidelberg, 2007, 83-122.

[7] Moreno-Amich R., Garcia-Berthou E., Hydrobiologia, 1989, 185: 83. DOI: 10.1007/ BF00006070.

[8] Roman C., Singh H., A Self-Consistent Bathymetric Mapping Algorithm, Journal of Field Robotics, 2007, 24(1-2), 23-50.

[9] Regulski K., Szeliga D., Kusiak J., Data Exploration Approach Versus Sensitivity Analysis for Optimization of Metal Forming Processes, Key Engineering Materials, Vol. 611-612, 2014, s. 1390-1395.

[10] Gao J., Bathymetric mapping by means of remote sensing: methods, accuracy and limitations, Progress in Physical Geography, 33(1), 2009, 103-116.

[11] Tripathi N. K., Rao A. M., Bathymetric mapping in Kakinada Bay, India, using IRS-1D LISS-III data, International Journal of Remote Sensing, 23(6), 2002, 1013-1025. 